Open Access

\title{
Chromosome number and ploidy level of balm (Melissa officinalis)
}

\author{
J. Kittler, O. Schrader, U. Kästner and F. Marthe*
}

\begin{abstract}
Background: Lemon balm (Melissa officinalis L.) is of increasing importance resulting in rising growth area. Improved knowledge on the genome structure, number of chromosomes in connection with the taxonomical structure of balm is indispensable for improved new varieties.

Results: A collection of 40 balm accessions (M. officinalis) was characterized by flow cytometry and FISH (18/25S and $5 \mathrm{~S}$ rDNA) to determine the chromosome number and ploidy level. Three different types were found: diploid genotypes with $2 n=2 x=32$ chromosomes; tetraploid $2 n=4 x=64$ chromosomes and triploid $2 n=3 x=48$ chromosomes. A haploid base number of $x=16$ chromosomes is likely. First time described triploid accessions are sterile but cytologically and morphologically stable for many years. Triploids express better winter hardiness and regeneration after harvesting cuts as well as bigger leaves and internodes.
\end{abstract}

Conclusions: A basic chromosome number of $x=16$ is reported for the first time for the species $M$. officinalis.

\begin{abstract}
Die wachsende Bedeutung von Zitronenmelisse (Melissa officinalis L.) führt zur Ausdehnung des hierfür erforderlichen Anbauumfanges. Ein verbesserter Kenntnisstand der Genomstruktur, der Chromosomenzahl und der hiermit in Zusammenhang stehenden taxonomischen Struktur der Melisse sind unerlässliche Voraussetzungen für verbesserte, neue Sorten.

Eine Kollektion von 40 Melisseherkünften (M. officinalis) wurde durchflusszytometrisch und durch FISH (18/25S and $5 \mathrm{~S}$ rDNA) untersucht, um den Ploidiegrad und die Chromosomenzahl zu ermitteln. Drei unterschiedliche Typen wurden konnten bestimmt werden: diploide Genotypen mit $2 n=2 x=32$ Chromosomen; tetraploide mit $2 n=4 x=64$ Chromosomen und triploide mit $2 n=3 x=48$ Chromosomen. Die haploide Chromosomenzahl ist mit $x=16$ anzunehmen. Die erstmalig beschriebenen triploiden Herkünfte sind steril aber zytologisch und morphologisch über viele Jahre stabil. Sie zeigen eine bessere Winterhärte und einen schnelleren Wiederaufwuchs nach Ernteschnitten, wie auch größere Blätter und Internodien.

Die Basischromosomenzahl von $\mathrm{x}=16$ wird erstmalig für die Art M. officinalis beschrieben.
\end{abstract}

\section{Background}

Lemon balm (Melissa officinalis L.) is an old crop and is used for phytopharmaceuticals, as an aromatic plant and in traditional folk medicine. A wide spectrum of secondary metabolites exists in lemon balm. For the medicinal use, the active ingredients essential oil with lemon fragrance and rosmarinic acid are necessary [6, 2, 3, 13].

\footnotetext{
* Correspondence: frank.marthe@jki.bund.de

Institute for Breeding Research on Horticultural Crops of the Julius Kuehn Institute (JKI), Federal Research Centre for Cultivated Plants, Erwin-Baur-Str. 27, Quedlinburg D-06484, Germany
}

\section{Biomed Central}

M. officinalis belongs to the family Labiatae (syn. Lamiaceae). This crop plant is grown worldwide but its origin is not well-defined, however the Mediterranean Region or western Asia is considered as the area of origin [9]. The subspecies M. officinalis L. ssp. officinalis and ssp. altissima (Sibth. \& Sm.) Arcangeli are distinguishable especially by the shape of calyx and density of different types of hairs $[5,20]$. The middle tooth of the three upper lip teeth of fruiting calyx is broadly triangular for ssp. officinalis whereas it is inconspicuous, truncate or 
emarginated for ssp. altissima. Pignatti [17] classified ssp. altissima as species $M$. romana.

The chromosome base number in Labiatae ranges from $\mathrm{x}=5$ to 11 , but also $\mathrm{x}=13,15,17$ and 19 occur [10]. For higher numbers, polyploidy is assumed followed by structural rearrangements. Chromosome numbers of 32 and 64 were reported for M. officinalis ssp. officinalis and ssp. altissima, respectively [20]. Ssp. altissima has been suggested as an ancestor of the cultivated diploid ssp. officinalis despite being tetraploid [9]. Davis [5] separated the ssp. inodora (Bornm.) Bornm. based on the long patent hairs on stems and fairly distinct, triangular middle tooth of upper calyx lip and mentioned intermediates between all three subspecies. Pignatti [17] described beside M. officinalis L. $(2 \mathrm{n}=32)$ the species $M$. romana Miller as synonymous with ssp. altissima because of the absence of any offspring $(2 \mathrm{n}=$ 64). Darlington and Wylie [4] presented the haploid chromosome number for $M$. officinalis with $\mathrm{x}=8$.

Lemon balm is of increasing importance, resulting in rising growth area and investigations for improved new varieties. Better winter hardiness, higher content of essential oil and higher yield of M. folium (lemon balm leaves) are of special interest in these programmes. Adaptation of technologies for acceleration of the breeding process using doubled haploid lines has been initiated. Therefore, the knowledge on the genome structure and number of chromosomes in connection with the taxonomical structure of $M$. officinalis is indispensable. In order to determine the ploidy level of 40 accessions and the chromosome number of the haploid M. officinalis genome, we employed flow cytometry and FISH using rDNA-specific probes. Beside di- and tetraploid accessions, first time triploid accessions $(2 n=3 \times=48)$ have been identified for M. officinalis.

\section{Results and discussion}

Genome size determination by flow cytometry of $M$. officinalis revealed for 23 accessions a diploid, four accessions a triploid and 13 accessions a tetraploid ploidy level (Table 1).

To confirm the ploidy predictions, chromosome numbers were determined and multicolour FISH was performed with $18 / 25 \mathrm{~S}$ - and $5 \mathrm{~S}$ rDNA-specific probes (Table 2). In M. officinalis $5 \mathrm{~S}$ and $18 / 25 \mathrm{~S}$ rDNA were localized on different chromosomes. Unlike this result in some other genera e.g. Helianthus, Brassica and Alstroemeria $[18,19,1]$ localization of $5 \mathrm{~S}$ and 18/25S rDNA on the same chromosome was found. Analysis of six selected accessions revealed for the putative diploid genotypes a chromosome number of 32 and two chromosome pairs exhibiting either 18/25S rDNA- or $5 \mathrm{~S}$ rDNA-specific signals (Fig. 1a, b). Putative triploid accessions contained 48 chromosomes and revealed six distinct hybridization signals: three $18 / 25 \mathrm{~S}$ rDNA and three $5 \mathrm{~S}$ rDNA (Fig. 1c, d). The last category exhibited 64 chromosomes and eight signals: four $18 / 25 \mathrm{~S}$ rDNA and four $5 \mathrm{~S}$ rDNA sites (Fig. 1e, f).

In accessions showing six or eight hybridization signals, the intensity of rDNA signals varied. Metaphases of accessions showing six signals displayed one strong and two weak 18/25S rDNA signals (Fig. 1c). The same was true for 5S rRNA sites. Metaphases of genotypes showing eight rDNA signals for each marker, one chromosome pair displayed a strong and one pair a weak hybridization signal (Fig. 1e). Hence accessions with 32 chromosomes and one pair of 18/25S rDNA and 5S rDNA signals are diploid $(2 \mathrm{n}=2 \times=32)$. Accessions with 48 chromosomes and three rDNA signals are triploid $(2 \mathrm{n}=3 \mathrm{x}=48)$, and accessions with 64 chromosomes and two pair of rDNA signals are tetraploid $(2 n=4 \times=48)$. Therefore, a chromosome basic number of $\mathrm{x}=16$ in the genus Melissa is likely. In contrast, Darlington and Wylie [4] postulated a basic chromosome number of $x=8$ and a somatic number of $2 \mathrm{n}=32$, without giving any information about investigated subspecies. Later on, Tutin et al. and Pignatti $[20,17]$ reported a chromosome number of $2 \mathrm{n}=32$ for $M$. officinalis ssp. officinalis. M. officinalis ssp. altissima and $M$. romana has $2 \mathrm{n}=64$ chromosomes [17, 20]. The reports of Heidari et al. [11] and Murin [15] of $2 n=32$ chromosomes and Löve [14] of $2 n=64$ chromosomes for $M$. officinalis provide no information about the analysed subspecies.

Two scenarios regarding the origin of triploid balm can be postulated: an unreduced gamete of a diploid plant formed triploid offspring after fertilization with a haploid gamete. Alternatively, a tetraploid parent hybridized with diploid parent and formed triploid offspring. The different signal intensity of either $5 \mathrm{~S}$ or $18 / 25 \mathrm{~S}$ rDNA sites in triploid balm could be explained by the different copy number of parental rDNA repeats.

\section{Phenotype characterization of triploid balm}

The plant phenotype of the four triploid accessions was characterized. Stems of the specimen BLBP 78, BLBP 88, BLBP 111 and BLBP 113 reached 120 to $140 \mathrm{~cm}$ (ssp. officinalis 50 to $80 \mathrm{~cm}$, [17]) with tendency of laying down and entangling. The size of leaves $(7.6 \mathrm{~cm}$ length, standard deviation s 0.59 and $5.4 \mathrm{~cm}$ width, s 0.56 ) was bigger than diploid ssp. officinalis type leaves $(6.9 \mathrm{~cm}$ length, standard deviation $\mathrm{s}$ 0.51 and $4.5 \mathrm{~cm}$ width, s 0.42 ). The internodes are longer $(9.4 \mathrm{~cm}$, standard deviation s 0.99$)$ in comparison with diploid ssp. officinalis $(6.5 \mathrm{~cm}, \mathrm{~s} 0.78)$ accessions (Table 3 ). Triploid accessions had very good cold resistance and regenerated faster after winter and harvesting cuts (results not shown). The colour of leaves 
Table 1 Determined ploidy level of balm accessions (Melissa officinalis) from Leibniz institute for plant genetics and crop plant research at Gatersleben, Germany (IPK) and bavarian state institute for agriculture at Freising, Germany (LfL) based on flow cytometry

\begin{tabular}{|c|c|c|c|c|}
\hline Accession No. & $\mathrm{COL}^{\mathrm{a}}$ & Taxonomical group of Melissa officinalis L. ${ }^{b}$ & Origin $^{b}$ & Ploidy level \\
\hline BLBP 5 & LfL & M. officinalis L. & southern France & diploid \\
\hline BLBP 8 & LfL & M. officinalis L. & Spain & diploid \\
\hline BLBP 19 & LfL & M. officinalis L. & Germany & diploid \\
\hline BLBP 27 & LfL & M. officinalis L. & Germany & diploid \\
\hline BLBP 33 & LfL & M. officinalis L. & botanical garden Halle, Germany & diploid \\
\hline BLBP 48 & LfL & M. officinalis L. & Germany & diploid \\
\hline BLBP 49 & LfL & M. officinalis L. & Unknown & diploid \\
\hline BLBP 50 & LfL & M. officinalis L. & Unknown & diploid \\
\hline BLBP 78 & LfL & M. officinalis L. & France & triploid \\
\hline BLBP 87 & LfL & M. officinalis L. & Georgia, landrace & diploid \\
\hline BLBP 88 & LfL & M. officinalis L. & botanical garden Liege, France & triploid \\
\hline BLBP 111 & LfL & M. officinalis L. & Hungary & triploid \\
\hline BLBP 113 & LfL & M. officinalis L. & France & triploid \\
\hline MELI 1 & IPK & M. officinalis L. & Unknown & diploid \\
\hline MELI 2 & IPK & M. officinalis L. & Unknown & diploid \\
\hline MELI 4 & IPK & M. officinalis L. & East Germany & diploid \\
\hline MELI 5 & IPK & M. officinalis L. 'Erfurter Aufrechte' & East Germany & diploid \\
\hline MELI 6 & IPK & M. officinalis L. & Germany & diploid \\
\hline MELI 7 & IPK & M. officinalis L. 'Citra' & Unknown & tetraploid \\
\hline MELI 8 & IPK & M. officinalis L. & Georgia & diploid \\
\hline MELI 10 & IPK & M. officinalis L. & France & diploid \\
\hline MELI 11 & IPK & M. officinalis L. 'ital. Melissa, Cedronella' & Italy & diploid \\
\hline MELI 12 & IPK & M. officinalis L. & Italy & tetraploid \\
\hline MELI 13 & IPK & M. officinalis L. & Georgia & diploid \\
\hline MELI 14 & IPK & M. officinalis L. subsp. altissima (Sibth. \& Sm.) Arcang. & Italy & tetraploid \\
\hline MELI 15 & IPK & M. officinalis L. subsp. altissima (Sibth. \& Sm.) Arcang. & Italy & tetraploid \\
\hline MELI 16 & IPK & M. officinalis L. subsp. officinalis & Unknown & diploid \\
\hline MELI 17 & IPK & M. officinalis L. & Greece & tetraploid \\
\hline MELI 18 & IPK & M. officinalis L. subsp. altissima (Sibith. \& Sm.) Arcang. & Unknown & tetraploid \\
\hline MELI 19 & IPK & M. officinalis $L$. & Italy & tetraploid \\
\hline MELI 20 & IPK & M. officinalis L. & Italy & tetraploid \\
\hline MELI 21 & IPK & M. officinalis L. subsp. altissima (Sibth. \& Sm.) Arcang. & Albania & tetraploid \\
\hline MELI 22 & IPK & M. officinalis L. & Turkey & tetraploid \\
\hline MELI 23 & IPK & M. officinalis L. subsp. altissima (Sibth. \& Sm.) Arcang. & Italy & tetraploid \\
\hline MELI 24 & IPK & M. officinalis L. subsp. altissima (Sibth. \& Sm.) Arcang. & Italy & tetraploid \\
\hline MELI 25 & IPK & M. officinalis L. 'Zitronenmelisse' & Unknown & diploid \\
\hline MELI 26 & IPK & M. officinalis L. & Armenia & diploid \\
\hline MELI 27 & IPK & M. sp. & Italy & diploid \\
\hline MELI 28 & IPK & M. officinalis L. & Italy & tetraploid \\
\hline D9597 & IPK & M. sp. 'Zitronenmelisse' & Unknown & diploid \\
\hline
\end{tabular}

${ }^{\mathrm{a} C O L}$ : collection

${ }^{b}$ taxonomical classification according to information of collection holders 
Table 2 Level of ploidy, number of chromosomes and signals resulting from FISH with 18/25S rDNA and 5S rDNA probes in accessions of balm (Melissa officinalis)

\begin{tabular}{lllll}
\hline Accession & $\begin{array}{l}\text { Number of } \\
\text { chromosomes }\end{array}$ & $\begin{array}{l}\text { Signals of 18/ } \\
\text { 25S rDNA }\end{array}$ & $\begin{array}{l}\text { Signals of 5S } \\
\text { rDNA }\end{array}$ & Ploidy \\
\hline BLBP 48 & 32 & 2 & 2 & diploid \\
MELI 1 & 32 & 2 & 2 & diploid \\
BLBP 78 & 48 & 3 & 3 & triploid \\
BLBP 113 & 48 & 3 & 3 & triploid \\
MELI 14 & 64 & 4 & 4 & tetraploid \\
MELI 22 & 64 & 4 & 4 & tetraploid \\
\hline
\end{tabular}

was bluish to greyish green in comparison to green leaves of ssp. officinalis (Fig. 2). Young leaves of triploid accessions have indumenta similar to ssp. altissima (Fig. 2) whereas according to Tutin et al. [20], leaves of diploid ssp. officinalis are glabrescent or sparsely hairy above, glandular-puberulent and more or less sparsely hairy beneath. Adult leaves of triploid accessions are more similar to ssp. officinalis. Stems of triploid accessions are greyish- or whitish-tomentose beneath with similarity to ssp. altissima. The triploid accessions are not lemon-scented. They had a soaplike, nauseating scent. These plants had an inconspicuous formation of flowers but do not produce any seed, neither under conditions of isolation nor by open pollination, likely due to meiotic problems. These first time described triploid accessions were propagated by cuttings and are cytologically and morphologically stable for at least six years.

\section{Conclusions}

The basic chromosome number of $\mathrm{x}=16$ is reported for the first time for the species M. officinalis and for family Labiatae.

This is the first characterization of triploids in $M$. officinalis. These triploid accessions are sterile but cytologically and morphologically stable. The length and width of the leaves and the length of internodes exceeded the comparable data for diploid accessions but are not significant for all characters.

For exact origin analysis of triploids as well as the characterization of allotetraploid or autotetraploid character of tetraploids analysis of meiotic chromosome pairing is necessary. Chromosome specific molecular markers would open the chance to ascertain the level of similarity of homoeologous groups of chromosomes. This is a prerequisite for better characterization of phylogenetic distance of $M$. officinalis ssp. altissima in comparison to ssp. officinalis.

\section{Material and methods}

\section{Plant materials}

A set of 40 accessions of $M$. officinalis have been characterized, of which 27 and 13 were provided from the Federal ex-situ Collection of Agricultural and Horticultural Plants of the Leibniz Institute for Plant Genetics and Crop Plant Research at Gatersleben, Germany (IPK) and the Bavarian State Institute for Agriculture at Freising, Germany (LfL) respectively. LfL collection contained old varieties and breeding material from middle and western Europe, the IPK collection includes mainly landraces and wild types from eastern and middle Europe (Table 1).

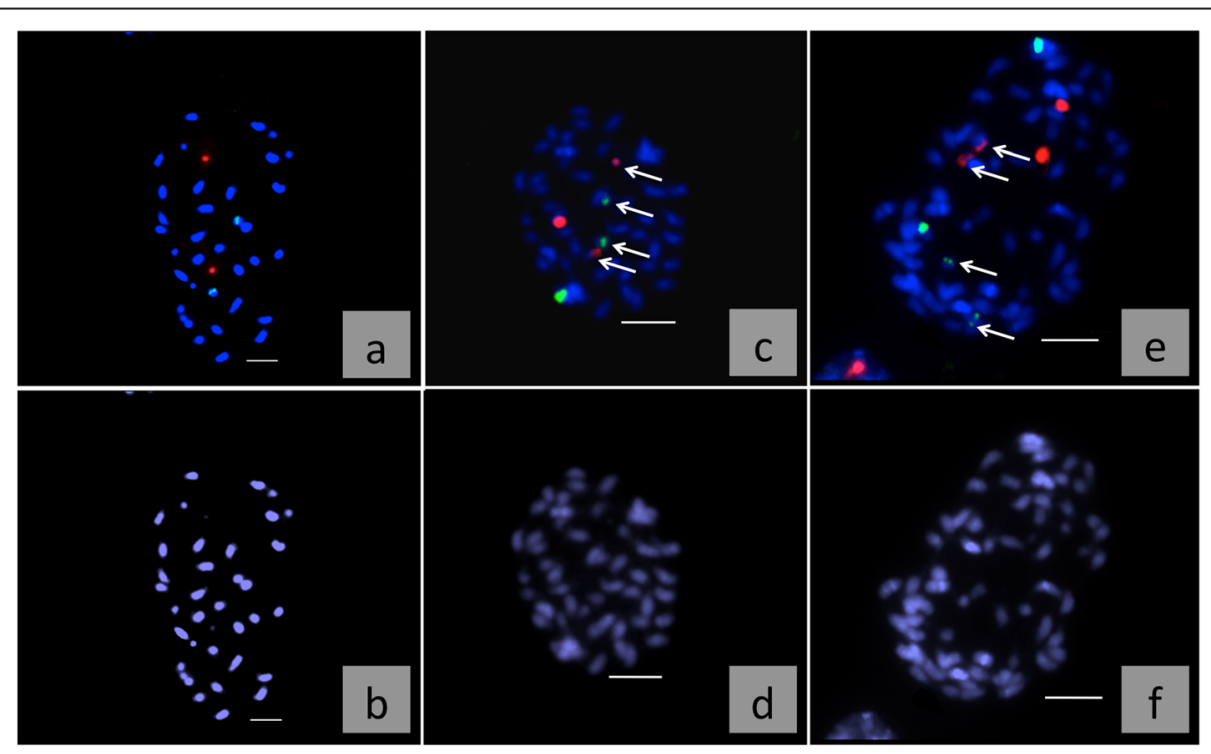

Fig. 1 a-f: Mitotic metaphase chromosomes of balm (Melissa officinalis) after FISH with 18/25S rRNA and 5S rRNA-specific probes. Above (a, c, e): FISH, red 18/25S rDNA, green 5S rDNA, arrows mark weak signals, below (b, d, f): DAPI stained chromosomes; a: diploid MELI 1, 2n = 2x = 32; : triploid BLBP 78, $2 n=3 x=48$, e: tetraploid MELI 22, $2 n=4 x=64$. The size bars equals $5 \mu m$ 
Table 3 Length and width of second leaf and length of second internode from base of stem for balm (Melissa officinalis) of different ploidy level

\begin{tabular}{|c|c|c|c|c|c|c|c|c|c|c|c|c|c|}
\hline \multirow{2}{*}{$\frac{\text { ploidy }}{\text { level }}$} & \multicolumn{4}{|c|}{ leaf length [cm] } & \multicolumn{4}{|c|}{ leaf width $[\mathrm{cm}]$} & \multicolumn{4}{|c|}{ internodes [cm] } & \multirow[t]{2}{*}{$\mathrm{n}^{\mathrm{b}}$} \\
\hline & Min & mean & $\max$ & $s^{a}$ & $\min$ & mean & $\max$ & $s^{a}$ & $\min$ & mean & $\max$ & $s^{a}$ & \\
\hline diploid & 6.2 & 6.9 & 7.5 & 0.51 & 4.0 & 4.5 & 5.1 & 0.42 & 5.8 & 6.5 & 8.3 & 0.78 & 9 \\
\hline triploid & 6.9 & 7.6 & 8.1 & 0.59 & 4.7 & 5.4 & 6.0 & 0.56 & 8.4 & 9.4 & 10.5 & 0.99 & 4 \\
\hline
\end{tabular}

$\mathrm{s}^{\mathrm{a}}$ standard deviation

$\mathrm{n}^{\mathrm{b}}$ number of accessions; For each accession at least ten plants were measured

All IPK accessions were grown from seeds whereas all LfL accessions were propagated by cuttings starting with a single plant. Radish (Raphanus sativus L.) was used as genome size marker in flow cytometry.

\section{Evaluation of ploidy level by flow cytometry}

Measuring of relative DNA amount of nuclei occurred by flow cytometry (Facs calibur, Becton Dickinson, BD) with a red fluorescence laser as basis for detection of ploidy level. For each probe, leaf material was chopped with razor blades in $500 \mu \mathrm{l}$ nuclei extraction buffer (CyStain PI absolute P, Sysmex) and stained with the corresponding staining buffer, containing $5 \%$ polyvinylpyrrolidone 25 (Serva) and $0.6 \%$ propidium iodide (Serva). Immediately after staining, the nuclei suspension was filtered using a $5 \mathrm{ml}$ polystyrene round-button tube with a cell-strainer cap (BD). For reference, radish was measured in separate sample after five samples of balm.

\section{Chromosome preparation}

M. officinalis seeds were germinated and the cell division synchronized with $1.25 \mathrm{mM}$ hydroxyurea for $17 \mathrm{~h}$. For vegetative multiplied accessions (LfL), root tips from potted plants were used. In contrast to Pan et al. [16], the recovery time after hydroxyurea treatment was $24 \mathrm{~h}$ at $6{ }^{\circ} \mathrm{C}$. Root tips were fixed in ethanol-acetic acid (3:1, $24 \mathrm{~h}$ ) and stored in $70 \%$ ethanol at $-20{ }^{\circ} \mathrm{C}$. After washing with aqua dest. root tips were digested with an enzyme mixture (4 \% cellulase, 'Onozuka R-10', Serva and $1 \%$ pectlyase Y-23 (Seishin Pharmaceutical)) in $75 \mathrm{mM} \mathrm{KCl}$ and $7.5 \mathrm{mM} \mathrm{Na-EDTA,} \mathrm{(pH} 4.0$ for $36 \mathrm{~min}$. at $37{ }^{\circ} \mathrm{C}$, [12]). Softened root tips were squashed in $45 \%$ acetic acid. After removal of the coverslip by freezing $\left(-84{ }^{\circ} \mathrm{C}\right)$ the slides were air dried overnight at $24{ }^{\circ} \mathrm{C}$ and stored at $-20^{\circ} \mathrm{C}$.

\section{Fluorescence in situ hybridization}

The 18S-5.8S-25S rDNA loci were detected with a 220 bp-long $25 \mathrm{~S}$ repeat-specific probe labelled with biotin-16-dUTP (Boehringer Mannheim) during polymerase chain reaction (PCR) amplification of the genomic DNA of Allium ampeloprasum with primers designed according to the sequence published by Yokota et al. [21]. For the localization of 5S rRNA genes, a 117 bp fragment obtained after PCR amplification from the same genomic DNA with specific primers coding for this region [8] was used. The labelling of this amplified probe was performed with digoxigenin-11-dUTP (Boehringer Mannheim). The hybridization mixture contained $80 \mathrm{ng}$ of each DNA probe (5S and $25 \mathrm{~S} \mathrm{rDNA}$ ) and $10 \mu \mathrm{g}$ of salmon-sperm DNA in $20 \mu \mathrm{l}$ of hybridization buffer (50\% deioinized formamide, $10 \%$ dextran sulphate, 2 x SSC) per slide [19].

The FISH procedure was performed according to Fuchs and Schubert [7] with the following modifications: prior to hybridization, slides were incubated in $50 \mathrm{ng} / \mu \mathrm{l}$ of DNase-free RNase in $2 \times$ SSC for $1 \mathrm{~h}$ at $37{ }^{\circ} \mathrm{C}$, washed three times in $2 \times \mathrm{SSC}$ for $5 \mathrm{~min}$ and treated with $0.5 \mathrm{ng} /$ $\mu \mathrm{l}$ of proteinase $\mathrm{K}$ for $10 \mathrm{~min}$ at $37^{\circ} \mathrm{C}$, followed by three times washing in $2 \times \mathrm{SSC}$ for $15 \mathrm{~min}$. The slides were then postfixed in $4 \%$ paraformaldehyde for $10 \mathrm{~min}$, washed three times in $2 \times$ SSC for $15 \mathrm{~min}$, dehydrated in a graded ethanol series $(70,80$ and $96 \%)$ at $-20{ }^{\circ} \mathrm{C}$, and air-dried. The hybridization mixture (probe) was denaturated $\left(80{ }^{\circ} \mathrm{C}\right.$, $7 \mathrm{~min}$ ), incubated on ice (about $5 \mathrm{~min}$ ), dropped onto

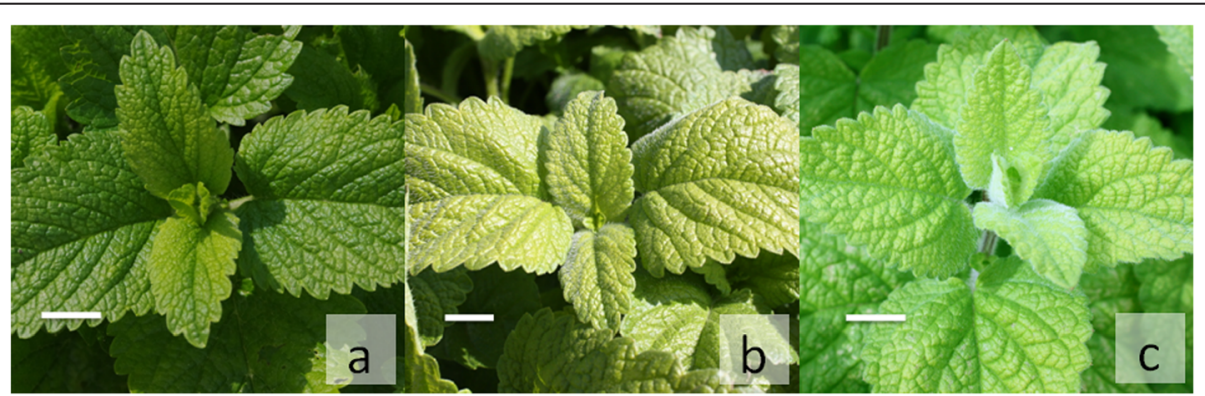

Fig. 2 leaf colour and density of pubescence in balm (Melissa officinalis); a: diploid, b: triploid and $\mathbf{c}$ : tetraploid. The size bars equals $1 \mathrm{~cm}$ 
slides, covered with coverslips, and sealed with rubber cement. Probes and chromosomes were denaturated together on a heated desk $\left(7 \mathrm{~min}, 80^{\circ} \mathrm{C}\right)$. The slides were then incubated overnight at $37{ }^{\circ} \mathrm{C}$ in a humidity chamber. After hybridization and removing the coverslips, the slides were washed in $2 \times \mathrm{SSC}$ at $37{ }^{\circ} \mathrm{C}$ three times for $5 \mathrm{~min}$ each, followed by three 5 min stringent washes in $0.3 \mathrm{x}$ SSC at $60{ }^{\circ} \mathrm{C}$ and then blocked for $30 \mathrm{~min}$ at $37^{\circ} \mathrm{C}$ with a solution of $4 \times$ SSC, $3 \%$ BSA and $0.1 \%$ Tween 20. The biotinylated probe was detected with $10 \mathrm{ng} / \mu \mathrm{l}$ of streptavidin-Cy3 (Dianova) and amplified with two steps of $10 \mathrm{ng} / \mu \mathrm{l}$ of biotinylated anti-streptavidin (Vector) and $10 \mathrm{ng} / \mu \mathrm{l}$ strepavidin-Cy3. Together with the first amplification step of the biotin labelled probe, the detection of the digoxigenin labelled probe with $9 \mathrm{ng} / \mu \mathrm{l}$ of anti-digoxigenin-fluorescein (Roche) was done and then amplified with $8 \mathrm{ng} / \mu \mathrm{l}$ anti-sheepfluorescein (Dianova). Chromosomes were counterstained and embedded in $15 \mu \mathrm{l}$ of DAPI-VECTASHIELD antifade solution (Vector Laboratories). Images were captured for each fluorescence dye separately with a cooled CCD camera system Axiocam (Zeiss) on a microscope Axioimager Z1 (Zeiss) with the following filter combinations: 02 (DAPI), 10 (FITC) and 20 (Cy3). Pseudocoloration and mergence of images were done with software of the Isis program (Metasystems).

\section{Competing interests}

The authors declare that they have no competing interests.

\section{Authors' contributions}

JK carried out the flow cytometry, measurement of leaves and internodes, chromosome preparation and performed the statistical analysis and drafted the manuscript. OS carried out fluorescence in situ hybridization. UK participated in the flow cytometry. FM conceived of the study, and participated in its design and coordination and helped to draft the manuscript. All authors read and approved the final manuscript.

\section{Acknowledgements}

The authors wish to acknowledge Dr U. Lohwasser, Leibniz Institute for Plant Genetics and Crop Plant Research at Gatersleben, Germany and Dr H. Heuberger, Bavarian State Institute for Agriculture at Freising, Germany for providing balm accessions. We are thankful to Dr W.D. Blüthner, Erfurt, Germany for critical discussions and Mrs. K. Maier for technical assistance. The project was funded by Fachagentur für Nachwachsende Rohstoffe FNR: 22019708 (08NR197) on behalf of the German Federal Ministry of Nutrition and Agriculture (BMEL).

Received: 14 July 2015 Accepted: 28 July 2015

Published online: 07 August 2015

\section{References}

1. Baeza C, Schrader O, Budahn H. Characterization of geographically isolated accessions in five Alstroemeria L. species (Chile) using FISH of tandemly repeated DNA sequences and RAPD analysis. PI Syst Evol. 2007;269:1-14.

2. Bomme U, Honermeier B, Hoppe B, Kittler J, Lohwasser U, Marthe F. Melisse (Melissa officinalis L.) (Balm (Melissa officinalis L.)). In: Hoppe B, editor. Handbuch des Arznei- und Gewürzpflanzenbaus (Handbook of medicinal and aromatic plants), vol. 5. Bernburg: Saluplanta; 2013. p. 151-73.

3. DAB. Deutsches Arzneibuch. Stuttgart: Deutscher Apothekerverlag; 2012. p. 2012.

4. Darlington CD, Wylie AP. Chromosome atlas of flowering plants. London: George Allen \& Unwin; 1955. p. 328.
5. Davis PH. Flora of turkey and the east Aegean islands, Vol. 7. Edinburg: University Press; 1982. p. 262-4.

6. European Union. Ph. Eur. 8. Pharmacopoea Europaea, 8th Ed., Stuttgart: Deutscher Apothekerverlag; 2014. p. 1799-1802..

7. Fuchs J, Schubert I. Localization of seed protein genes on metaphase chromosomes of Vicia faba via fluorescence in situ hybridization. Chromosom Res. 1995;3:94-100.

8. Gottlob-McHugh SG, Levesque M, Mackenzie K, Olson M, Yarosh O, Johnson DA. Organization of the $5 S$ ribosomal-RNA genes in the soybean Glycine max (L.) Merrill and conservation of the 5S rDNA repeat structure in higher plants. Genome. 1990;33:486-94.

9. Hanelt P, Institute of Plant Genetics and Crop Plant Research. Mansfeld's encyclopedia of agricultural and horticultural crops. Berlin, Heidelberg, New York: Springer; 2001. p. 1995-7.

10. Harley RM, Atkins S, Budantsev AL, Cantino PD, Conn BJ, Grayer R, et al. Labiatae. In: Kubitzki K, editor. The families and genera of vascular plants. Vol. VII Kadereit JW, Flowering plants dicotyledons lamiales (except Acanthaceae including Avicenniaceae. Berlin, Heidelberg, New York: Springer; 2004. p. 176-7.

11. Heidari P, Mehrabi AA. Nasrolah Nezhad Ghomi AA. Cytogenetic diversity of Iranian balm (Melissa officinalis) landraces and genetic relationship within and between them using ITS markers. Biharean Biologist. 2013;7(2):94-8.

12. Kakeda K, Fukui K, Yamagata H. Heterochromatic differentiation in barley chromosomes revealed by C- and N-banding techniques. Theor Appl Genet. 1991;81:144-50.

13. Krüger H, Schütze W, Lohwasser U, Marthe F. Qualität bei Melisse - gestern und heute: Hydroxyzimtsäurederivate versus Rosmarinsäure, vergleichende Untersuchungen an einer Melissenkollektion (Melissa officinalis L.) (Quality of melissa-yesterday and today: hydroxycinnamic acid derivatives versus rosmarinic acid, comparative investigations of a Melissa collection (Melissa officinalis L.)). Z Arznei- Gewürzpfla. 2010;15(1):31-2.

14. Löve A. IOBP chromosome number reports LXXVIII. Taxon. 1983;32:138-41.

15. Murin A. Karyotaxonomy of some medicinal and aromatic plants. Thaiszia. 1997;7:75-88.

16. Pan WH, Houben A, Schlegel R. Highly effective cell synchronization in plant roots by hydroxyurea and amiprophos-methyl or colchicine. Genome. 1993:36:387-90.

17. Pignatti S. Flora d'Italia (Flora of Italy), vol. 2. Bologna: Edagricole; 1982. p. 475.

18. Schrader O, Ahne R, Fuchs J, Schubert I. Karyotype analysis of Helianthus annuus using Giemsa banding and fluorescence in situ Hybridization. Chromosom Res. 1997:5:451-6.

19. Schrader O, Budahn H, Ahne R. Detection of $5 \mathrm{~S}$ and $25 \mathrm{~S}$ rRNA genes in Sinapis alba, Raphanus sativus and Brassica napus by double fluorescence in situ hybridization. Theor Appl Genet. 2000;100:665-9.

20. Tutin TG, Heywood VH, Burges NA, Moore DM, Valentine DH, Walters SM, et al. Flora europaea. Vol. 3, Diapensiaceae to Myoporaceae. Cambridge: University Press; 1972. p. 162-3.

21. Yokota Y, Kawata T, lida Y, Kato A, Tanifuji S. Nucleotide-sequences of the 5.8S ribosomal-RNA gene and internal transcribed spacer regions in carrot and broad bean. J Mol Evol. 1989;29:294-301.

\section{Submit your next manuscript to BioMed Central and take full advantage of:}

- Convenient online submission

- Thorough peer review

- No space constraints or color figure charges

- Immediate publication on acceptance

- Inclusion in PubMed, CAS, Scopus and Google Scholar

- Research which is freely available for redistribution 